\title{
Bulan Ramadan dan Kebahagiaan Seorang Muslim
}

\author{
Royanulloh $^{1}$, Komari $^{2}$ \\ ${ }^{1,2}$ UIN Walisongo, Jl. Walisongo No. 3-5 Kota Semarang \\ e-mail: royanulloh@walisongo.ac.id
}

\begin{abstract}
Abstrak
The Islamic and the Nusantara tradition shows that Ramadan is always welcomed with joy. Therefore, Ramadan is related to happiness. This quantitative research analyzes how changes in happiness occur as the coming of Ramadan. The respondents are 117 muslims adult who have received pesantren education. The results showed that significant differences in positive emotions between weeks 3, 2, and 1 before the coming of Ramadan. Meanwhile, negative emotions did not show a significant decrease. Then, the correlation test results show there is a positive correlation between the arrival of Ramadan with positive emotions. Meanwhile, the correlation test was negative with negative emotions. This research proves the coming of the month of Ramadan associated with increasing happiness of a muslim.
\end{abstract}

Dalam tradisi Islam maupun nusantara, bulan Ramadan terbiasa disambut dengan penuh suka cita. Oleh karena itu, bulan Ramadan diduga berkaitan dengan kebahagiaan. Penelitian kuantitatif ini bertujuan menganalisa perubahan kebahagiaan pada seorang muslim seiring datangnya bulan Ramadan. Responden berjumlah 117 orang muslim dewasa yang pernah mengenyam pendidikan pesantren. Hasil penelitian memperlihatkan perbedaan emosi positif yang signifikan antara minggu ke-3, ke-2, dan ke-1 menjelang datangnya bulan Ramadan, sementara emosi negatif tidak menunjukkan penurunan yang signifikan. Hasil uji korelasi memperlihatkan terdapat korelasi positif antara datangnya bulan Ramadan dengan emosi positif, serta sebaliknya berkorelasi negatif dengan emosi negatif. Hal ini membuktikan datangnya bulan Ramadan berkaitan dengan peningkatan kebahagiaan seorang muslim.

\section{Pendahuluan}

Bulan Ramadan merupakan bulan istimewa bagi umat Islam. Pada bulan ini, kaum muslimin diwajibkan menjalankan ibadah puasa selama satu bulan penuh. Ibadah puasa dilaksanakan dari terbit hingga terbenam matahari (Syam, 2017). Aktivitas puasa ini membuat bulan Ramadan pun menjadi bulan dengan nuansa yang sangat berbeda. Bulan Ramadan merupakan bulan ibadah. Dalam keyakinan seorang muslim, ibadah pada bulan Ramadan menjanjikan banyak pahala dari Allah Swt. (Syam, 2017; Zaprulkhan, 2007). Bulan Ramadan menjadi semakin istimewa, karena di dalamnya terdapat peristiwa turunnya Alquran dan malam Lailatul Qadr. Dalam ajaran Islam, malam Lailatul Qadr adalah malam dimana rahmat dan ampunan Allah melimpah ruah yang
Keywords/ Kata kunci

muslim;

ramadan;

happiness muslim;

bulan ramadan;

kebahagiaan mampu membersihkan dosa-dosa yang telah lalu (Syam, 2017).

Kaum muslimin pun sangat menanti-nanti kehadiran bulan Ramadan. Saat waktunya tiba, dengan gegap gempita semboyan "Marhaban Ya Ramadan" menyebar dalam kesehariannya. Poster-poster dengan semboyan tersebut bertebaran, baik di jalan, di media massa, bahkan hingga di media sosial. Bulan Ramadan menawarkan hal-hal positif di dalamnya. Adanya hal-hal positif yang menyenangkan dapat membuat seseorang merasakan kegembiraan (Muhopilah, Gamayanti, \& Kurniadewi, 2018).

Nuansa gembira menyambut bulan Ramadan pun tertuang dalam salah satu hadis. Rasulullah Saw. bersabda: "Barangsiapa bergembira dengan masuknya Bulan Ramadan, Allah akan mengharamkan jasadnya masuk neraka". Dalam tradisi ulama-ulama salaf 
terdahulu, terkenal ucapan doa yakni: "Ya Allah sampaikanlah aku dengan selamat ke Ramadan, selamatkan Ramadan untukku, dan selamatkanlah aku hingga selesai Ramadan”.

Dalil maupun doa yang disebutkan, secara langsung menegaskan bahwa bagi seorang muslim rasa bahagia ketika bulan Ramadan datang adalah sebuah keniscayaan. Rasa bahagia ini pun diekspresikan dengan amalanamalan khusus. Dalam tradisi Islam, setidaknya ada tiga amalan saat menyambut bulan Ramadan, yakni: (1) amalan hati berupa keikhlasan dan rasa gembira, (2) berziarah ke makam orang tua yang telah mendahului, dan (3) saling memaafkan antar sesama (Hadrawy, 2012; Syam, 2017).

Di Indonesia, dapat disaksikan adanya beberapa tradisi unik dalam menyambut bulan Ramadan. Tradisi-tradisi ini sangat beragam, yang berlangsung di berbagai daerah di Indonesia. Di Aceh, terdapat tradisi makan daging bersama semua kalangan masyarakat, yang disebut Meugang. Tradisi ini telah bertahan selama 400 tahun, menjadi simbol rasa bahagia menyambut bulan Ramadan (Bona, 2019). Di daerah Kudus, Jawa Tengah, masyarakat memiliki tradisi yang disebut Dandangan. Kegiatannya berupa tarian kolosal yang diselenggarakan di alun-alun Kudus. Tarian kolosal ini menceritakan mulai dari sejarah industri pengolahan tembakau di Kudus hingga sejarah Sunan Kudus (Monoarfa, 2018).

Di daerah Jawa Barat, tepatnya di Cileunyi Kabupaten Bandung, terdapat tradisi permainan bola api. Permainan ini dilaksanakan di malam pertama Ramadan, dilakukan oleh 10 orang anak yang dibagi menjadi dua kelompok (Bona, 2019). Sementara, di Indonesia bagian timur, khususnya di Dusun Macera, Desa Mammi, Kecamatan Binuang, Polewali Mandar, Sulawesi Barat. Di daerah ini berkembang tradisi Mabbaca-baca. Dalam ritual tradisi ini, warga menyajikan nasi ketan, kari ayam, telur, dan buah-buahan, serta membakar pallang atau lilin tradisional yang terbuat dari kapas dan biji kemiri. Tradisi ini merupakan ungkapan doa agar pemilik rumah diberi petunjuk dan kekuatan dalam menjalankan ibadah puasa yang penuh dengan ujian kesabaran dan kejujuran (Monoarfa, 2018).

Tradisi-tradisi yang telah dikemukakan memperlihatkan betapa pentingnya kehadiran bulan Ramadan bagi seorang muslim Indonesia. Selain persoalan ritual ibadah, bulan Ramadan juga bertaut dengan tradisi, sehingga pengaruhnya semakin kuat dan mengakar serta memengaruhi kehidupan sehari-hari seorang muslim. Segala kebiasaan berubah, sebisa mungkin perbuatan baik selalu dilaksanakan, sementara perbuatan jelek mesti ditinggalkan. Hal ini mengubah pola perilaku, gaya hidup, hingga perubahan psikologis (Syam, 2017).

Secara psikologis, baik tradisi Islam maupun beberapa tradisi budaya nusantara yang telah disebutkan, memperlihatkan adanya penguatan kebahagiaan yang muncul menjelang bulan Ramadan. Dalam hal ini, terdapat kecenderungan perubahan emosi positif saat bulan Ramadan datang. Tradisi Islam maupun tradisi nusantara, memandang bulan Ramadan sebagai bulan yang penuh dengan kesempatan melakukan perbuatan baik. Dalam Islam, kebahagiaan akan datang salah satunya saat perbuatan baik dilakukan manusia (Sodiq, 2016). Bulan Ramadan pun merupakan bulan pencerahan spiritual, yang mampu meningkatkan kesejahteraan secara psikologis, sehingga berimplikasi pada kebahagiaan (Zaprulkhan, 2007).

Kebahagiaan sejatinya merupakan tujuan umum yang ingin diraih oleh banyak orang (Lyubomksky, Sheldon, \& Schkade, 2005). Maka seseorang cenderung mendekatkan dirinya kepada faktor-faktor atau situasi yang memudahkan kebahagiaan itu diraih. Ia pun akan merasa nyaman saat berada pada kondisi yang mampu membahagiakan dirinya. Seorang individu dapat mengatur faktor-faktor ini menjadi sebuah mekanisme hidup yang mendatangkan kebahagiaan mendalam (Buss, 2000). Kebahagiaan ini ditempuh untuk meningkatkan kualitas hidup, sehingga keberadaannya menjadi sangat penting (Costanza, Fisher, Ali, Beer, Bond, Boumans, \& Snapp, 2007). 
Kebahagiaan dapat dirasakan karena faktor internal maupun faktor eksternal, seperti halnya keberadaan bulan Ramadan bagi umat Islam. Kebahagiaan juga merupakan hal yang subjektif (Costanza dkk., 2007), suatu hal yang menyebabkan kebahagiaan bagi seseorang atau sekelompok orang, belum tentu menyebabkan kebahagiaan pada orang atau kelompok lainnya. Maka, kebahagiaan pun dapat berkaitan dengan lingkungan. Bagi komunitas muslim, bulan Ramadan secara subjektif menjadi sumber kebahagiaan.

Kondisi bahagia memengaruhi keadaan seseorang secara keseluruhan, baik itu keadaan sosial maupun emosi. Saat seseorang sedang bahagia, ia merasakan perasaan positif pada sebagian besar waktunya, meskipun demikian sesekali dapat muncul perasaan negatif (Diener \& Seligman, 2002). Hal ini pun dinyatakan oleh Carra (2013), bahwa kebahagiaan sebagai keadaan psikologis yang positif, ditandai oleh tingginya tingkat emosi positif dan rendahnya tingkat emosi negatif. Dengan demikian, salah satu indikator yang dapat dijadikan tolak ukur kebahagiaan adalah keadaan emosi positif dalam dirinya. Semakin sering emosi positif dirasakan pada suatu periode waktu tertentu, maka semakin bahagia orang tersebut. Artinya, orang yang bahagia merasakan emosi positif tertentu yang lebih sering dibandingkan dengan emosi negatif.

Berdasarkan uraian di atas, kehadiran bulan Ramadan diduga berkaitan dengan kebahagiaan. Artinya diduga emosi positif meningkat lebih tinggi ketika bulan Ramadan tiba serta sebaliknya, emosi negatif cenderung menurun. Penelitian ini bertujuan menganalisa penguatan kebahagiaan ditinjau dari perubahan emosi positif dan negatif menjelang bulan Ramadan pada seorang muslim. Bulan Ramadan dalam penelitian ini dilihat sebagai sebuah momen atau peristiwa, sehingga eksplorasi kebahagiaan difokuskan pada waktu menjelang kedatangannya. Penelitian ini berusaha membuktikan secara empiris, bahwa bagi seorang muslim kedatangan bulan
Ramadan dapat menjadi faktor yang mampu meningkatkan kebahagiaannya.

\section{Metode}

Metode yang digunakan dalam penelitian ini adalah metode kuantitatif. Hal ini dimaksudkan untuk menemukan data empiris berupa angka, mengenai kebahagiaan seorang muslim saat menghadapi bulan Ramadan. Kebahagiaan seorang muslim berkaitan dengan bulan Ramadan seringkali dinyatakan dalam keseharian dan tertuang dalam teks-teks dalil, baik hadis maupun Alquran. Adapun yang berbasis data berupa angka belum banyak dieksplorasi terutama melalui penelitian kuantitatif.

Penelitian ini menggunakan analisis korelasional, untuk melihat arah dan kekuatan hubungan antara variabel bulan Ramadan dan kebahagiaan. Untuk memudahkan analisis secara statistik, kedua variabel diterjemahkan ke dalam angka.

Variabel bulan Ramadan diterjemahkan menjadi waktu, diukur berdasarkan jarak waktu dalam minggu menuju bulan Ramadan. Dalam proses pengambilan data, responden terbagi ke dalam tiga kelompok berdasarkan waktu. Kelompok 1 adalah kelompok yang diukur tingkat kebahagiaannya pada 3 minggu sebelum Ramadan. Kelompok 2 adalah kelompok yang diukur pada 2 minggu sebelum Ramadan. Sementara, kelompok 3 adalah kelompok yang diukur pada 1 minggu sebelum Ramadan. Setiap kelompok masing-masing terdiri dari 39 responden, sehingga jumlah total responden sebanyak 117 orang. Ketiga kelompok terdiri dari orang-orang yang berbeda.

Responden penelitian diperoleh berdasarkan teknik purposive sampling. Berdasarkan kriteria berikut: 1) dewasa, 2) beragama Islam, dan 3) berstatus sebagai santri atau setidaknya pernah mondok selama mengenyam pendidikan tingkat dasar, menengah, baik SMP maupun SMA. Hal ini dimaksudkan agar penghayatan terhadap kedatangan Ramadan lebih kuat, sehingga relevan untuk dianalisa pengalaman emosi positif dan negatif yang dialami. 
Untuk analisis secara statistik, proses penskoran menggunakan pedoman berikut: semakin dekat waktu dengan Ramadan, semakin meningkat skor waktunya. Dengan demikian, kelompok 1 akan memperoleh skor waktu 1, kelompok 2 akan memperoleh skor 2 , dan kelompok 3 akan memperoleh skor 3.

Sementara itu, ukuran kebahagiaan akan dianalisa menggunakan alat ukur berupa kuesioner The Positive and Negative Affect Schedule (PANAS). Alat ukur ini merupakan salah satu alternatif menganalisa tingkat kebahagiaan individu dengan mengukur seberapa besar emosi positif dan negatif dirasakan pada suatu kondisi tertentu.

Secara konseptual, kebahagiaan ditandai dengan kondisi psikologis yang positif, dimana tingkat emosi positif lebih tinggi dibanding tingkat emosi negatif (Carra, 2013). Berdasarkan konsep ini, maka alat ukur PANAS relevan untuk digunakan dalam penelitian. Kuesioner PANAS valid untuk digunakan pada dua kondisi emosi, yakni positif dan negatif, baik pada kelompok pelajar maupun dewasa (Brdar, 2014; Crawford \& Henry, 2004; Watson, Clark, \& Tellegen, 1988). Dengan munculnya emosi positif dan negatif, maka analisa kebahagiaan dapat dilakukan lebih detail. Kuesioner PANAS disusun untuk mengukur keadaan emosi seseorang pada jangka waktu tertentu, bisa kondisi hari ini, seminggu terakhir, atau satu tahun terakhir, sesuai dengan konteks analisis yang dibutuhkan (Brdar, 2014).

PANAS questionnaire terdiri dari 20 item berupa kata-kata yang menggambarkan keadaan emosi tertentu. Kuesioner terdiri dari masingmasing 10 kata berupa emosi negatif dan positif (Thompson, 2007). Responden diminta mengukur rentang keadaan emosi pada masingmasing item. Ukuran keadaan emosi disimbolkan menggunakan angka dari 1 sampai 5 . Angka 1 menunjukkan suatu kondisi emosi tidak intens dirasakan, sedangkan angka 5 menunjukkan kondisi emosi sangat intens dirasakan (Brdar, 2014). Masing-masing kelompok item, yakni emosi positif dan negatif, diskor secara terpisah. Skor maksimal pada masing-masing kelompok item adalah 50 . Semakin dekat skor ke angka maksimal tersebut, maka kondisi emosi dirasakan semakin kuat. Agar pengisian kuesioner sesuai dengan konteks datangnya bulan Ramadan, maka kuesioner dibuka dengan pertanyaan pembuka pada kuesioner sebagai berikut: "Bulan Ramadan akan datang 3/2/1 minggu lagi. Saat membayangkan akan datangnya bulan Ramadan, seberapa sering perasaanperasaan di bawah ini Anda rasakan?".

\section{Hasil}

Hasil penelitian memperlihatkan adanya perubahan emosi positif dan negatif pada seorang muslim seiring semakin dekatnya bulan Ramadan. Keadaan emosi positif seorang muslim mengalami peningkatan menjelang Ramadan. Berdasarkan data pada gambar 1, rata-rata skor emosi positif responden mengalami kenaikan. Skor rata-rata emosi positif pada kelompok yang diamati 3 minggu sebelum Ramadan sebesar 35.1. Kelompok 2 minggu sebelum memiliki skor rata-rata sebesar 37.7. Sementara, kelompok 1 minggu sebelum memiliki skor rata-rata kebahagiaan sebesar 38.1 .

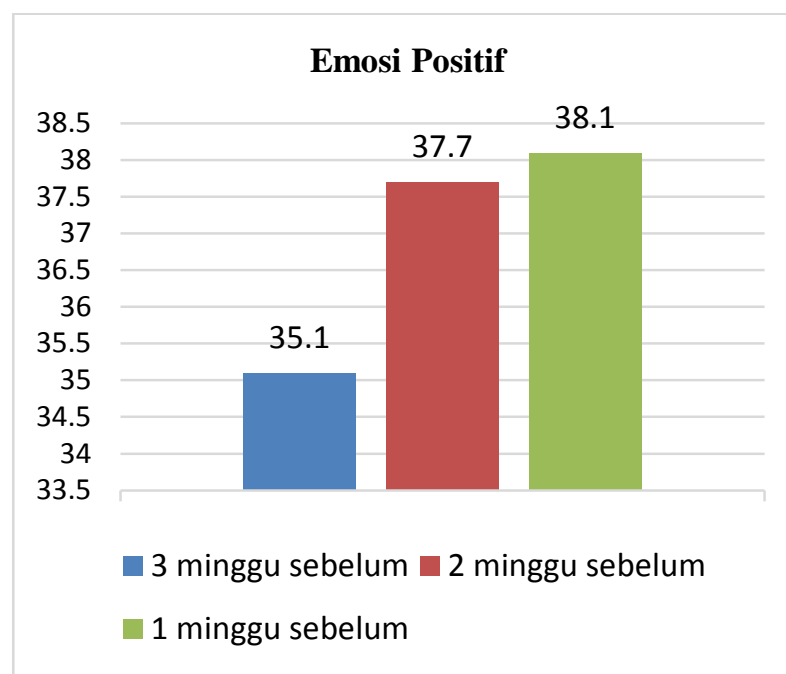

Gambar 1. Fluktuasi Emosi Positif Menjelang Bulan Ramadan 


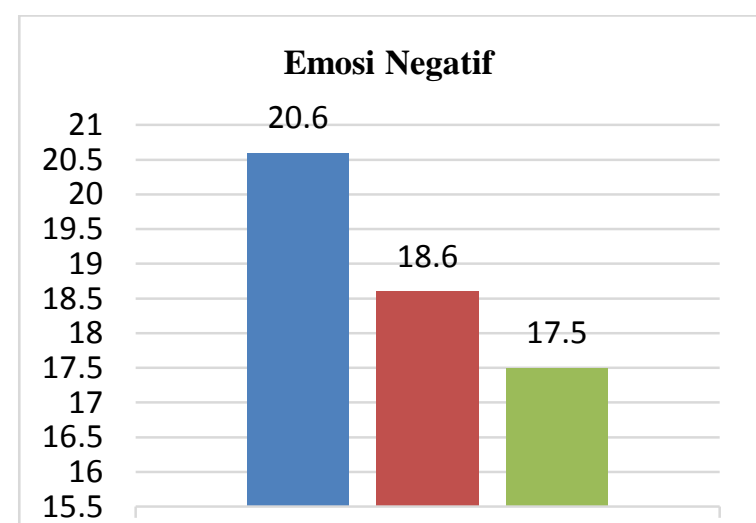

3 minggu sebelum $\square$ minggu sebelum

1 minggu sebelum

Gambar 1. Fluktuasi Emosi Negatif Menjelang Bulan Ramadan

Kondisi sebaliknya dapat diamati pada emosi negatif. Pada gambar 2, skor rata-rata emosi negatif semakin menurun seiring makin dekatnya bulan Ramadan. Pada kelompok yang diamati 3 minggu sebelum Ramadan, rata-rata skor emosi negatifnya sebesar 20.6. Sementara itu, pada kelompok 2 minggu sebelum Ramadan, skor rata-rata emosi negatifnya adalah 18.6. Skor ini makin menurun pada kelompok 1 minggu sebelum Ramadan, menjadi sebesar 17.5.

Penelitian juga menemukan perbedaan rata-rata intensitas emosi yang dirasakan, antara emosi positif dan negatif pada masing-masing kelompok. Data secara konsisten memperlihatkan emosi positif selalu lebih tinggi dibanding emosi negatif.

Tabel 1

Perbedaan Rata-rata Skor Emosi Positif dan Negatif

\begin{tabular}{lcc}
\hline \multicolumn{1}{c}{$\begin{array}{c}\text { Kelompok } \\
\text { Responden }\end{array}$} & $\begin{array}{c}\text { Rata-rata Skor } \\
\text { Emosi Positif }\end{array}$ & $\begin{array}{c}\text { Rata-rata Skor } \\
\text { Emosi Negatif }\end{array}$ \\
\hline $\begin{array}{l}\text { Tiga minggu } \\
\text { sebelum bulan }\end{array}$ & 35.1 & 20.6 \\
$\begin{array}{l}\text { Ramadan } \\
\text { Dua minggu } \\
\text { sebelum bulan }\end{array}$ & 37.7 & 18.6 \\
$\begin{array}{l}\text { Ramadan } \\
\text { Satu minggu } \\
\text { sebelum bulan }\end{array}$ & 38.1 & \\
Ramadan & & 17.5 \\
\hline
\end{tabular}

Tabel 2

Hasil Uji One Way Anova Perbedaan Emosi Positif

\begin{tabular}{llllll}
\hline & $\begin{array}{c}\text { Sum of } \\
\text { Squares }\end{array}$ & df & $\begin{array}{c}\text { Mean } \\
\text { Square }\end{array}$ & F & Sig. \\
\hline $\begin{array}{l}\text { Between } \\
\text { Groups }\end{array}$ & 207.846 & 2 & 103.923 & 4.08 & .019 \\
$\begin{array}{l}\text { Within } \\
\text { Groups } \\
\text { Total }\end{array}$ & 2906.154 & 114 & 25.493 & & \\
\hline
\end{tabular}

Tabel 3

Hasil Uji One Way Anova Perbedaan Emosi Negatif

\begin{tabular}{lccccc}
\hline & $\begin{array}{c}\text { Sum of } \\
\text { Squares }\end{array}$ & df & $\begin{array}{c}\text { Mean } \\
\text { Square }\end{array}$ & F & Sig. \\
\hline $\begin{array}{l}\text { Between } \\
\text { Groups }\end{array}$ & 198.068 & 2 & 99.034 & 2.91 & .058 \\
Within & & & & & \\
$\begin{array}{l}\text { Groups } \\
\text { Total }\end{array}$ & 3873.897 & 114 & 33.982 & & \\
\hline
\end{tabular}

Tabel 1 memperlihatkan, baik pada waktu 3 minggu sebelum, 2 minggu sebelum, dan 1 minggu sebelum bulan Ramadan, rata-rata skor emosi positif selalu lebih tinggi dibandingkan skor rata-rata emosi negatif. Data-data menegaskan emosi positif semakin sering dirasakan menjelang tibanya bulan Ramadan dibandingkan dengan emosi negatif.

Untuk menegaskan data perbedaan ini, maka dilakukan uji beda one way anova karena akan menganalisis ada atau tidaknya perbedaan tiga kelompok independen. Uji one way anova bisa dilakukan jika data yang digunakan memenuhi syarat normalitas dan homogenitas. Hasil uji normalitas melalui tes Kolmogorovsmirnov memperlihatkan kedua kelompok data berdistribusi normal dengan nilai signifkansi masing-masing data sebesar .567 (data emosi positif) dan sebesar .604 (data emosi negatif). Kedua nilai berada di atas taraf signifikansi penelitian, yakni .05. Sementara itu, hasil uji homogenitas berdasarkan test of homogenity variance memperlihatkan nilai masing-masing data .559 (data emosi positif) dan .266 (data emosi negatif). Kedua nilai tersebut memenuhi uji homogenitas karena berada di atas taraf signifikansi .05 .

Setelah dilakukan uji normalitas dan homogenitas, berlanjut pada uji one way anova. Uji one way anova fokus pada analisa 
perbedaan kondisi emosi positif dan negatif pada kelompok minggu ketiga, kedua, dan pertama menjelang bulan Ramadan. Hasil uji disajikan pada tabel 2 dan 3 .

Tabel 2 memperlihatkan terdapat perbedaan emosi positif yang signifikan dengan nilai signifikansi sebesar .019 $(<\alpha ; \alpha=.05)$. Hal ini membuktikan adanya kenaikan emosi positif seorang muslim dengan datangnya bulan Ramadan. Sementara tabel 3 memperlihatkan nilai signifikansi sebesar .058 ( $>\alpha ; \alpha=.05)$, sehingga perbedaan kondisi emosi negatif tidak signifikan. Penurunan emosi negatif dapat dikatakan tidak terjadi cukup kuat dengan datangnya bulan Ramadan. Hasil-hasil ini memperlihatkan kebahagiaan dapat meningkat, ditopang oleh semakin meningkatnya emosi positif seorang muslim dengan kedatangan bulan Ramadan.

Selanjutnya berdasarkan hasil uji korelasi rank-spearman, diperoleh hasil sebagai berikut: 1) Hasil uji korelasi antara emosi positif dengan waktu menjelang Ramadan menunjukkan koefisien korelasi sebesar .255 dengan signifkansi .006 ( $\alpha=.05 ; \mathrm{N}=117)$ sebagaimana disajikan pada tabel 4; dan 2) Hasil uji korelasi antara emosi negatif dengan waktu menjelang Ramadan menunjukkan koefisien korelasi sebesar -.288 dengan signifikansi .014 ( $\alpha=.05$; $\mathrm{N}=117)$ sebagaimana disajikan pada tabel 5 .

Dalam analisis korelasional kekuatan hubungan dilihat berdasarkan angka koefisien korelasi yang bergerak dari 0 hingga 1 . Jika hasil analisa semakin mendekati angka 1, maka semakin kuat korelasi antara kedua variabel. Sebaliknya, jika hasil analisa semakin mendekati nol, maka semakin lemah korelasinya (Coolican, 2018).

Angka koefisien korelasi dapat bernilai positif atau negatif. Hal ini menunjukkan arah hubungan antar variabel (Coolican, 2018). Jika angka positif, maka kedua variabel bergerak ke arah yang sama. Saat satu variabel mengalami kenaikan, variabel lain yang berkorelasi mengalami hal yang sama, begitu pun sebaliknya. Jika angka negatif, maka kedua variabel bergerak ke arah yang berbeda. Ketika satu variabel mengalami kenaikan, variabel lain yang berkorelasi mengalami penurunan, begitu pun sebaliknya.

Hasil analisis statistik memperlihatkan terdapat korelasi yang signifikan antara emosi positif maupun negatif dengan waktu menjelang Ramadan. Emosi positif berkorelasi positif dengan kedatangan bulan Ramadan. Artinya, semakin dekat Ramadan semakin meningkat emosi positif seorang muslim. Sementara, emosi negatif berkorelasi negatif dengan kedatangan bulan Ramadan. Artinya, seorang muslim semakin sedikit merasakan emosi negatif saat Ramadan datang. Semakin besarnya emosi positif dirasakan dibandingkan emosi negatif, semakin besar perasaan bahagia yang dirasakan seseorang.

Tabel 4

Hasil Uji Korelasi Emosi Positif dengan Kedatangan Bulan Ramadan

\begin{tabular}{|c|c|c|c|}
\hline Spear & lan's Rho & $\begin{array}{l}\text { Emosi } \\
\text { Positif }\end{array}$ & $\begin{array}{c}\text { Waktu } \\
\text { Menuju } \\
\text { Ramadan }\end{array}$ \\
\hline \multirow{3}{*}{$\begin{array}{l}\text { Emosi } \\
\text { Positif }\end{array}$} & Koefisien & 1.000 & $.255^{* *} *$ \\
\hline & $\begin{array}{l}\text { Sig. } \\
\text { (2- tailed) }\end{array}$ & & .006 \\
\hline & $\mathrm{N}$ & 117 & 117 \\
\hline \multirow{3}{*}{$\begin{array}{l}\text { Waktu } \\
\text { Menuju } \\
\text { Ramadan }\end{array}$} & $\begin{array}{l}\text { Koefisien } \\
\text { Korelasi }\end{array}$ & $.255^{* *}$ & 1.000 \\
\hline & $\begin{array}{l}\text { Sig. } \\
\text { (2- tailed) }\end{array}$ & .006 & \\
\hline & $\mathrm{N}$ & 117 & 117 \\
\hline
\end{tabular}

Tabel 5

Hasil Uji Korelasi Emosi Negatif dengan Kedatangan Bulan Ramadan

\begin{tabular}{|c|c|c|c|}
\hline \multicolumn{2}{|c|}{ Spearman's Rho } & $\begin{array}{c}\text { Emosi } \\
\text { Negatif }\end{array}$ & $\begin{array}{c}\text { Waktu } \\
\text { Menuju } \\
\text { Ramadan }\end{array}$ \\
\hline \multirow[t]{3}{*}{$\begin{array}{l}\text { Emosi } \\
\text { Negatif }\end{array}$} & $\begin{array}{l}\text { Koefisien } \\
\text { Korelasi }\end{array}$ & 1.000 & $-.228 *$ \\
\hline & $\begin{array}{l}\text { Sig. } \\
\text { (2- tailed) }\end{array}$ & & .014 \\
\hline & $\mathrm{N}$ & 117 & 117 \\
\hline \multirow{3}{*}{$\begin{array}{l}\text { Waktu } \\
\text { Menuju } \\
\text { Ramadan }\end{array}$} & $\begin{array}{l}\text { Koefisien } \\
\text { Korelasi }\end{array}$ & $-.228 *$ & 1.000 \\
\hline & $\begin{array}{l}\text { Sig. } \\
\text { (2- tailed) }\end{array}$ & .014 & \\
\hline & $\mathrm{N}$ & 117 & 117 \\
\hline
\end{tabular}




\section{Diskusi}

Hasil perbedaan rata-rata emosi positif yang signifikan menunjukkan adanya peningkatan keadaan emosi positif seiring makin dekatnya bulan Ramadan. Hal ini memperlihatkan bulan Ramadan mampu mendorong emosi positif seorang muslim, sehingga suasana kebahagiaan lebih mudah dirasakan. Namun demikian, rasa bahagia yang dirasakan tidak berarti menurunkan emosi negatifnya. Artinya, suasana pengalaman terkait emosi negatif masih dirasakan, namun intensitasnya lebih rendah dirasakan, dibandingkan emosi positif.

Hal ini bisa dijelaskan dalam hasil analisis korelasi, dimana korelasi antara emosi positif dan datangnya bulan Ramadan bernilai positif, sedangkan korelasi antara emosi negatif dan datangnya bulan Ramadan bernilai negatif. Hal ini menunjukkan perasaan seorang muslim saat Ramadan datang berada dalam keadaan yang positif, sehingga mereka sedang dalam kondisi bahagia.

Bulan Ramadan adalah bulan yang unik bagi komunitas muslim. Bulan ini sangat ditunggu kehadirannya dan menawarkan pengalaman yang berbeda dari bulan-bulan sebelumnya (Syam, 2017; Zaprulkhan 2007). Dalam hal ritual ibadah, bulan ini menawarkan insentif positif, berupa pahala yang berlipat pada setiap kebaikan dan ibadah yang dilaksanakan. Hal ini menjadi salah satu pokok keyakinan dalam ajaran Islam. Umat Islam pun berbondong-bondong mengejar insentif ini. Maka, ia akan lebih bersemangat menjalankan ibadah sehari-hari. Masjid semakin ramai, nuansa religius pun semakin kuat. Pengalaman melaksanakan ibadah menjadi lebih menyenangkan dibandingkan bulan sebelumnya (Zaprulkhan, 2007).

Hal ini memudahkan orang untuk lebih intens beribadah. Apalagi ditunjang dengan keyakinan setiap ibadah bernilai pahala berlipat-lipat (Syam, 2017). Usaha menjalankannya pun terasa semakin ringan, seiring ajaran dalam Islam yang menyatakan setansetan dibelenggu selama bulan Ramadan. Hal ini terdapat dalam hadis riwayat Bukhari dan Muslim, Rasulullah Saw. bersabda: "Ketika masuk bulan Ramadan, maka syaitan-syaitan dibelenggu, pintu-pintu surga dibuka, dan pintu-pintu neraka ditutup". Perasaan bahagia dalam menjalankan ibadah pun dapat semakin besar dirasakan (Zaprulkhan, 2007).

Nuansa kebahagiaan pada bulan Ramadan pun terkait dengan ibadah puasa. Aktivitas puasa ini diawali dengan makan sahur dan diakhiri dengan makan berbuka puasa. Pada banyak keluarga muslim, aktivitas ini seringkali menjadi ajang makan bersama-sama dengan keluarga, kerabat, rekan kerja, hingga kawan lama (Hidayat, 2016; Khozin, 2017), sehingga momen ini menjadi salah satu momen istimewa. Berbagai kemudahan diterima untuk memudahkan jalannya peristiwa makan bersama ini. Misalnya, jam kerja selama Ramadan disesuaikan, biasanya kantor-kantor memberikan kebijakan jam kerja yang lebih pendek. Jam masuk kerja menjadi lebih lambat, sementara jam pulang kerja menjadi lebih cepat. Hal ini memudahkan seorang muslim menjalani aktivitas makan bersama, baik pada saat sahur maupun berbuka puasa (Khozin, 2017).

Selain puasa, Ramadan diisi dengan beragam aktivitas ibadah rutin mulai dari tadarus Alquran, pengajian-pengajian, sholat tarawih berjamaah, hingga i'tikaf pada minggu terakhir bulan Ramadan. Aktivitas ibadah ini tidak sekedar dilaksanakan sendiri, tetapi dilaksanakan secara berjamaah. Tidak jarang, aktivitas ibadah pun menjadi ajang bertatap muka dengan tetangga atau orang lainnya. Nuansa positif dapat terasa, dengan adanya pengalaman bertegur sapa atau sekedar melepas rindu orang-orang yang sudah lama tidak bertemu (Zaprulkhan, 2007).

Dalam tradisi nusantara, terdapat pula halhal yang membentuk nuansa positif bulan Ramadan. Selain tradisi acara-acara adat untuk menyambutnya, bulan Ramadan juga identik dengan makanan-makanan khas yang biasanya jarang ditemukan pada bulan-bulan lainnya. Salah satunya adalah "kolak", olahan makanan manis untuk berbuka puasa. Makanan olahan 
ini dijual di berbagai tempat. Bahkan, banyak penjual musiman untuk jenis makanan ini, yang hanya berjualan di bulan Ramadan. Ataupun, mereka menambah item yang dijual dengan berbagai macam jenis kolak berharap meningkatkan omzet penjualan mereka (Hidayat, 2016).

Tradisi lain, yang tidak kalah unik dan menarik perhatian tersendiri adalah mudik lebaran. Mudik adalah aktivitas pulang ke kampung halaman menjelang Ramadan berakhir. Tradisi ini bahkan secara masif hanya terjadi di Indonesia, melibatkan pergerakan jutaan orang dari kota-kota besar di seluruh Indonesia (Soebyakto, 2011). Tradisi mudik adalah suatu kewajiban, seberapa mahal ataupun sulitnya dilakukan, muslim di Indonesia pasti akan menjalaninya (Iriyanto, 2012). Oleh karena itu, Ramadan pun dipersepsi sebagai saatnya pulang, berjumpa dengan orang tua, anak dan suami/ istri, hingga sanak-saudara lainnya. Maka, betapa bahagianya para muslim yang merantau ketika bulan Ramadan datang. Apalagi di Indonesia, banyak sekali masyarakat yang merantau, baik untuk tujuan sekolah maupun bekerja, meninggalkan kampung halamannya (Iriyanto, 2012).

Hal-hal ini memperlihatkan, baik dalam tradisi Islam maupun tradisi nusantara, kedatangan bulan Ramadan berkaitan dengan nuansa kebahagiaan seorang muslim. Suasana bahagia yang membangun nuansa bahagia dalam Ramadan, mampu mendorong terjadinya peningkatan emosi positif dalam diri muslim di Indonesia, sehingga bulan Ramadan tidak bisa dilepaskan dari keadaan kebahagiaan.

Kebahagiaan merupakan sisi positif dalam dimensi psikologis manusia (Carra, 2013; Seligman \& Csikszentmihalyi, 2014; Seligman, Steen, Park, \& Peterson, 2005). Kebahagiaan menjadi salah satu landasan utama dalam kajian mempelajari manusia yang sehat, baik secara fisik maupun psikologis (Diener \& Seligman, 2002). Kebahagiaan dalam konstruk psikologis adalah suatu keadaan dimana emosi positif lebih dirasakan dibandingkan emosi negatif (Carra, 2013; Taufiq, 2012).

Naik turunnya dua emosi yaitu positif dan negatif menjadi komponen penting dalam menentukan kebahagiaan. Dalam kondisi bahagia, tidak berarti emosi negatif menghilang 100 persen. Kedua emosi selalu berada beriringan, saling berganti mana yang muncul dan mana yang tenggelam. Dengan demikian, meskipun emosi positif dirasakan, emosi negatif tetap dapat muncul (Carra, 2013). Hal ini terlihat dalam data penelitian, dimana emosi negatif tetap muncul meskipun lebih banyak emosi positif yang dirasakan. Namun demikian, Ramadan lebih kuat menaikkan kebahagiaan dibandingkan menurunkannya.

Keadaan fluktuasi ini bersesuaian dengan konteks situasi di sekitarnya. Semakin dekat seseorang dengan situasi yang membahagiakan dirinya, maka semakin besar kebahagiaan yang dirasakan (Costanza dkk., 2007; Rahardjo, 2007). Seseorang memiliki kecenderungan untuk mendekatkan diri pada situasi yang membahagiakan (Buss, 2000). Situasi ini seringkali bersifat subjektif, sesuai dengan pemaknaan terhadap suatu keadaan. Hal ini mafhum terjadi, secara konsep kebahagiaan dilandasi pengalaman subjektif berkaitan dengan emosi positif yang paling bermakna (Costanza dkk., 2007; Rahardjo, 2007).

Kebahagiaan merupakan konstruk unik yang memiliki aspek-aspek kontekstual yang kuat (Anggoro \& Widhiarso, 2010). Hal ini terjadi dalam fenomena Ramadan bagi seorang muslim. Bulan Ramadan, bagi seorang muslim, memiliki makna yang mendalam. Tradisi-tadisi yang dijalankan, baik dalam konteks Islam maupun kultur budaya, membuat penghayatan akan makna bulan Ramadan semakin kuat. Bulan Ramadan menjadi salah satu peristiwa personal yang menawarkan keuntungan psikologis sehingga kebahagiaan dapat dirasakan (Harmaini \& Yulianti, 2014). Rasa bahagia pun semakin kuat, karena dalam bulan Ramadan terdapat banyak kesempatan melakukan kebaikan, dimana dalam Islam 
kebahagiaan diyakini datang bagi orang-orang yang melakukannya (Sodiq, 2016).

Bulan Ramadan mampu menjadi sumber kebahagiaan karena bulan ini pun merupakan ruang untuk mengekspresikan keimanan, dimana kegiatan beribadah maupun berbuat baik pada sesama dapat dilakukan dengan bebas, ditunjang oleh suasana yang positif. Hal ini dapat mendatangkan kebahagiaan, karena bagi seorang muslim iman adalah salah satu penyebab munculnya kenyamanan hidup, ketenangan, hingga kebahagiaan dalam kehidupan (Najati, 2004).

Penelitian ini merupakan salah satu penelitian empiris yang berupaya menjelaskan adanya kebahagiaan berkaitan dengan bulan Ramadan berbasis data kuantitatif. Penelitian ini berhasil mengolah data bagaimana dinamika kebahagiaan seorang muslim saat datangnya Ramadan, ditinjau dari fluktuasi emosi positif dan negatif yang dirasakan. Penelitian ini tidak dirancang untuk mengeksplorasi kebahagiaan secara mendalam. Namun demikian, penelitian ini dapat memberi sumbangsih sebagai sumber data bagi penelitian lain tentang bulan Ramadan dan kebahagiaan yang lebih mendalam. Penelitian ini pun dapat menjadi model untuk melakukan penelitian kuantitatif dalam konteks perilaku keagamaan di masyarakat.

Penelitian ini memiliki beberapa keterbatasan. Diantaranya, penelitian fokus pada eksplorasi secara kuantitatif saat Ramadan datang, tetapi belum sampai menjelaskan pada bagaimana eksplorasi kebahagiaan dalam bulan Ramadan itu sendiri. Dengan demikian, pengembangan penelitian masih dapat dikembangkan ke arah tersebut. Namun demikian, jika penelitian serupa dapat dilakukan, maka untuk memperkuat analisa peningkatan kebahagiaan, dapat menggunakan responden yang sama pada setiap waktu pengamatan/ pengukuran kebahagiaan menjelang datangnya bulan Ramadan.

Selain itu, penelitian masih terbatas pada kelompok santri yang memiliki ikatan kuat dengan peristiwa keagamaan seperti bulan Ramadan. Akan sangat menarik apabila penelitian diperluas jangkauannya pada partisipan dengan karakteristik lain, di luar kelompok santri. Hal ini dapat memberikan gambaran yang lebih luas secara kuantitatif, mengenai bulan Ramadan dan peningkatan kebahagiaan. Penelitian pun masih dapat dikembangkan, misalnya dengan studi eksperimen atau kuasi eksperimen, melalui pengamatan/ pengukuran kebahagiaan sebelum dan setelah bulan Ramadan dilalui.

Penelitian kuantitatif dalam konteks perilaku beragama, seperti halnya penelitian bulan Ramadan dan peningkatan kebahagian ini, tidak serta-merta menafikan eksplorasi mendalam melalui studi kualitatif. Tentu saja studi kualitatif adalah hal yang penting dalam penelitian semacam ini, terutama dalam rangka memberikan informasi yang komprehensif dan mendalam.

Namun demikian, metode kuantitatif dapat menghasilkan data yang lebih cepat serta dapat dipahami lebih mudah, sehingga semakin membumikan studi Psikologi dalam konteks perilaku beragama, khususnya dalam model penelitian kuantitatif. Dengan demikian, diharapkan perilaku beragama dapat dipahami dalam literatur-literatur penelitian, tidak hanya melalui teks-teks agama saja, yang lebih banyak membutuhkan ahli untuk menerjemahkannya.

\section{Simpulan}

Penelitian ini membuktikan kaitan antara datangnya bulan Ramadan dengan kebahagiaan seorang muslim. Kaitan antara datangnya bulan Ramadan dengan kebahagiaan seorang muslim dapat disarikan ke dalam dua karakteristik utama. Pertama, datangnya bulan Ramadan berkaitan dengan menguatnya emosi positif yang dirasakan. Kedua, datangnya bulan Ramadan berkaitan dengan melemahnya emosi negatif yang dirasakan. Temuan ini menjadi bukti empiris, khususnya secara statistik, bahwa kebahagiaan yang dirasakan seorang muslim ketika bertemu bulan Ramadan bukanlah kebetulan semata. Penguatan emosi positif tidak serta-merta menghilangkan emosi negatif. Namun demikian, datangnya bulan Ramadan 
dapat menjadi media untuk menekan emosi negatif dalam diri dan menjadi momen positif yang mendatangkan rasa bahagia.

\section{Referensi}

Anggoro, W. J., \& Widhiarso, W. (2010). Konstruksi dan identifikasi properti psikometris instrumen pengukuran kebahagiaan berbasis pendekatan indigenous psychology: Studi multitraitmultimethod. Jurnal Psikologi, 37(2), 176188.

Bona. (2019, 4 Mei). Aneka tradisi sambut ramadan di Indonesia. Diunduh dari detikTravel:

https://travel.detik.com/domesticdesination/d-4536198/aneka-tradisisambut-ramadan-di-indonesia

Brdar, I. (2014). Positive and negative affect schedule (PANAS). In Encyclopedia of Quality of Life and Well-Being Research. doi: 10.1007/978-94-007-0753-5_2212

Buss, D. M. (2000). The evolution of happiness. American Psychologist, 55(1), 15-23. doi: 10.1037/0003-066X.55.1.15

Carra, A. (2013). Positive Psychology: The Science of Happiness and Human Strengths, Second Edition. doi: 10.4324/9780203156629

Coolican, H. (2018). Research methods and statistics in psychology. Research Methods and Statistics in Psychology. DOI: 10.4324/9781315201009

Costanza, R., Fisher, B., Ali, S., Beer, C., Bond, L., Boumans, R., \& Snapp, R. (2007). Quality of life: An approach integrating opportunities, human needs, and subjective well-being. Ecological Economics, 61(23), 267-276. doi: 10.1016/j.ecolecon.2006.02.023

Crawford, J. R., \& Henry, J. D. (2004). The positive and negative affect schedule (PANAS): Construct validity, measurement properties and normative data in a large non-clinical sample. British Journal of Clinical Psychology. doi: 10.1348/0144665031752934

Diener, E., \& Seligman, M. E. P. (2002). Very happy people. Psychological Science, 13, 81-84. doi:10.1111/1467-9280.00415

Hadrawy, U. (2012, 12 Juli). Ubudiyah. Diunduh dari NU Online: https://www.nu.or.id/post/read/38775/amal an-menyambut-ramadan

Harmaini, H., \& Yulianti, A. (2014). Peristiwaperistiwa yang membuat bahagia. Psympathic: Jurnal Ilmiah Psikologi, 1(2), 109-119. doi:10.15575/psy.v1i2.472

Hidayat, A. (2016). Budaya konsumen bulan ramadan bagi masyarakat modern di Indonesia. IBDA : Jurnal Kajian Islam dan Budaya. doi: 10.24090/ibda.v14i2.684

Iriyanto, A. (2012). Mudik dan keretakan budaya. Humanika: Jurnal Ilmiah Kajian Humaniora.

Khozin, M. (2017). Sukses ramadan. Aswaja NU Center PWNU Jatim dan Pengurus Pusat Lajnah Ta'lif Wan Nasyr (LTN PBNU).

Lyubomksky, S., Sheldon, K. M., \& Schkade, D. (2005). Pursuing happiness: The architecture of sustainable change. Review of General Psychology, 9(2), 111-131 doi:10.1037/1089-2680.9.2.111

Monoarfa, J. (2018, 4 Juni). 5 Tradisi Unik Ramadan di Nusantara. Diunduh dari regional kompas: https://regional.kompas.com/jeo/5-tradisiunik-ramadan-di-nusantara

Muhopilah, P., Gamayanti, W., \& Kurniadewi, E. (2018). Hubungan kualitas puasa dan kebahagiaan santri pondok pesantren Alihsan. Jurnal Psikologi Islam dan Budaya. 1(1), 53-66. doi:10.15575/jpib.v1i1.2071

Najati, M. 'U. (2004). Psikologi dalam perspektif hadis. Jakarta: Pustaka Al Husna Baru.

Rahardjo, W. (2007). Kebahagiaan sebagai suatu proses pembelajaran. Jurnal Penelitian Psikologi.

Seligman, M. E. P., \& Csikszentmihalyi, M. (2014). Positive psychology: An introduction. In Flow and the Foundations of Positive Psychology: The Collected Works of Mihaly Csikszentmihalyi. doi:10.1007/978-94-017-9088-8_18

Seligman, M. E. P., Steen, T. A., Park, N., \& Peterson, C. (2005). Positive psychology progress: Empirical validation of interventions. The American psychologist, 60(5), 410-421. doi:10.1037/0003066X.60.5.410

Sodiq, A. (2016). Konsep kesejahteraan dalam Islam. Equilibrium, 3(2), 380-405 doi.org/110.21043/equilibrium.v3i2.1268

Soebyakto, B. B. (2011). Mudik lebaran: studi 
kualitatif. Jurnal Ekonomi Pembangunan.

Syam, Y. H. (2017). Materi puasa ramadan. Elmatera: Yogyakarta

Taufiq. (2012). Positive psychology: Psikologi cara meraih kebahagiaan. Prosiding Seminar Nasional Psikologi Islami.

Thompson, E. R. (2007). Development and validation of an internationally reliable short-form of the Positive and Negative Affect Schedule (PANAS). Journal of Cross-Cultural Psychology, 38(2), 227242. doi:10.1177/0022022106297301
Watson, D., Clark, L. A., \& Tellegen, A. (1988). Development and validation of brief measures of positive and negative affect: The PANAS scales. Journal of Personality and Social Psychology, 54(6), 1063-1070. doi:10.1037/0022-3514.54.6.1063

Zaprulkhan. (2007). Puasa ramadan sebagai terapi pencerahan spiritual. Jakarta: Hikmah. 
BULAN RAMADAN DAN KEBAHAGIAAN SEORANG MUSLIM 